ISSN 1392-3196 / e-ISSN 2335-8947

Zemdirbyste-Agriculture, vol. 102, No. 3 (2015), p. 297-304

DOI $10.13080 / \mathrm{z}-\mathrm{a} .2015 .102 .038$

\title{
The quantity of biologically active substances in purple coneflower as influenced by the preparation methods and drying technologies
}

\author{
Aušra ČIPLIENE $\dot{E}^{1}$, Audrius MARUŠKA ${ }^{2}$, Algirdas RAILA ${ }^{1}$, Egidijus ZVICEVIČIUS ${ }^{1}$, \\ Ona RAGAŽINSKIENË ${ }^{3}$, Mantas STANKEVIČIUS ${ }^{2}$
}

${ }^{1}$ Aleksandras Stulginskis University

Studentų 15, Akademija, Kaunas distr., Lithuania

E-mail: ausra.cipliene@asu.lt

${ }^{2}$ Vytautas Magnus University

Vileikos 8, Kaunas, Lithuania

${ }^{3}$ Kaunas Botanical Garden of Vytautas Magnus University

Ž. E. Žilibero 6, Kaunas, Lithuania

\begin{abstract}
The purple coneflower (Echinacea purpurea (L.) Moench) is one of the most promising medicinal plants in Lithuania. More than 200 biologically active substances, and the most important components among them phenolic acids, including chicoric acid are accumulated in the medicinal plant raw material. Moisture content of purple coneflower raw material can reach up to $80 \%$ just after harvest, thus different drying technologies are used to reduce moisture content and this process involves losses of bio-active substances. An experimental comparative research was carried out to determine the influence of preparation and drying methods of purple coneflower for drying process and quality. It was found that weight of purple coneflower stems accounted for $48.7 \%$ of the total plant weight and they formed the largest above-ground part of a plant, which was by 1.5 and 2.6 times higher than the weight of leaves and flowers, respectively. In flowers, leaves and stems of purple coneflower, phenolic acids constituted the biggest part of phenolic compounds. The distribution of phenolic acids in different above-ground plant parts was from $64.66 \pm 3.23$ to $92.08 \pm 4.60 \mathrm{mg} \mathrm{g}_{\mathrm{dm}}{ }^{-1} \mathrm{RE}$ (rutin equivalent) in flowers, from $47.46 \pm 2.37$ to $76.9 \pm 3.85 \mathrm{mg} \mathrm{g}_{\mathrm{d} . \mathrm{m} .}{ }^{-1} \mathrm{RE}$ in leaves and from $15.2 \pm 1.05$ to $22.99 \pm 1.15 \mathrm{mg} \mathrm{g}_{\mathrm{d} . \mathrm{m} .}{ }^{-1} \mathrm{RE}$ in stems.
\end{abstract}

Key words: biologically active compounds, drying technology, medicinal plants.

\section{Introduction}

In recent decades, throughout Europe, including Lithuania, consumption of plants with healing and aromatic properties is gaining popularity in everyday life (Mačkinaitè, 2011). Their physiological and healthrelated properties depend on the composition and amount of biologically active substances present within plant cells. The most important biologically active substances are phenolic compounds (simple phenols, flavonoids, phenolic acids, coumarins, tannins, lignins, etc.), alkaloids, glycosides, essential oils, ferments, organic substances, vitamins and macro- and micro-elements. Amounts of the substances accumulated in a plant depend on the plant genotype, climatic and growing conditions, chemical composition of the soil (Diatta et al., 2014); harvesting time, plant age and medicinal raw material preparation and drying technologies have a strong influence on the amount as well (Müller, Heindl, 2006; Sárosi et al., 2013; Argyropoulos, Müller, 2014).

More than 460 naturally growing and introduced medicinal-aromatic plant species are used in Lithuania
(Ragažinskienè, Rimkienè, 2003; Raila et al., 2009; Zvicevičius et al., 2013). One of the most popular medicinal plants is purple coneflower. It originates from NorthAmerica and is widespread in its Central and Eastern parts (Dambrauskienè, 2006; Mistríková, Vaverková, 2007). Purple coneflower was brought to Europe at the end of the $17^{\text {th }}$ century and has been grown in Lithuania since the 1960s (Dambrauskienè, 2006). The total area of the world's industrially grown purple coneflower fields comprises a few thousand hectares (Abbasi et al., 2007). There are no natural purple coneflower growing places in Lithuania. Purple coneflower readily adapts to the predominant seasonal weather patterns, overwinters easily and can be grown in the same place for even up to seven years (Dambrauskienè, 2006; Raila et al., 2014). All above-ground and underground parts of the plant are used as medicinal raw material. Literary sources indicate that purple coneflower accumulates up to 216 different components of biologically active substances (Murch et al., 2006; Abbasi et al., 2007). The most 
common biologically active substances are alkamides, derivatives of caffeic acid (chicoric acid), flavonoids, polysaccharides, lectins, essential oils (Lin et al., 2011; Tsai et al., 2012). The purple coneflower grown in Lithuania is characterised by a generous amount of chicoric acid, its amount in plants could reach up to $4.72 \%$ (Raila et al., 2014). More than 70 different purple coneflower preparations are produced in Europe for the prevention or treatment of various allergic, autoimmune and cancerous diseases (Dambrauskiené, 2006; Abbasi et al., 2007; Lin et al., 2011).

After harvesting, purple coneflower as well as other herbaceous medicinal plants is characterized by a high moisture content, which can be higher than $80 \%$ (Lin et al., 2011; Zvicevičius et al., 2013). In medicinal plant raw material of such moisture content favourable conditions for the activity of micro-organisms, as well as for the degradation of bio-active substances are formed (Prickett et al., 2000; Lugauskas et al., 2002). In order to suppress the biochemical processes and the growth of micro-organisms, medicinal plant raw material should be dried.

During drying of the plant raw material, considerable amount of water is evaporated; weight of the material is reduced, while at the same time its transportation and storage costs are reduced. However, along with it a part of biologically active substances is lost (Arabhosseini et al., 2007). Regardless of the species of a medicinal-aromatic plant, its morphological part or purpose, it is indicated that drying of medicinal-aromatic plants, which accumulate non-volatile active substances, is recommended at $50-100^{\circ} \mathrm{C}$ (Müller, Heindl, 2006). After drying the purple coneflower at a temperature of $40-70^{\circ} \mathrm{C}$, it was determined that the higher temperature of drying agent increased losses of phenolic compounds, as well as losses of chicoric acid (Kim et al., 2000; Stuart, Wills, 2003; Lin et al., 2011). Many researchers have analysed various drying methods used for purple coneflower: freeze-drying, vacuum microwave and convection drying (Kim et al., 2000; Stuart, Wills, 2003; Lin et al., 2011). However, we lack more detailed data on the influence of methods of the medicinal plant raw material preparation for drying and time of drying on the biologically active substances.

The aim of the research is to carry out a comparative study and to identify the influence of purple coneflower's (Echinaceae purpureae (L.) Moench) preparation for drying on the drying process and preservation of its quality.

\section{Materials and methods}

The above-ground part of purple coneflower, grown in the Vytautas Magnus University Botanical Garden in the collection of medicinal plants and spice herbs, was used in the research work. The medicinal plant raw material was harvested in 2012 and 2013 in the second half of July. The harvested purple coneflower herb was separated into blossoms, stems and leaves. Three samples (each weighting $4 \mathrm{~kg}$ ) were taken from each separated morphological part of a plant.
Study on the drying. The study was carried out in 2012-2013 at a laboratory of the Institute of Energy and Biotechnology Engineering, Aleksandras Stulginskis University. At the beginning of the drying study, moisture content of medicinal plant raw material was determined in accordance with Lithuanian standard LST 1530:2004. For determination of moisture content 8 samples were randomly taken from different places of mound, and before and after drying their weight was recorded using scales SC ALTEC SPO 51 (Scaltec Instruments GmbH, Germany), accuracy $\pm 0.01 \mathrm{~g}$. The samples were dried for 24 hours at $105^{\circ} \mathrm{C}$ in the oven Memmert UPF 700 (Memmert GmbH, Germany).

Study on the drying of an elementary layer. Samples of whole leaves, flowers and stems, sliced into chunks of $248 \pm 7 \mathrm{~mm}$ length on average were taken for the experiment with three repetitions. Part of the flower and stem samples had been additionally prepared for the experiment: flowers were crushed, while stems were crushed or chopped to $22.1 \pm 0.7 \mathrm{~mm}$ particles. The test samples were spread in a thin layer on the special $2 \times 2 \mathrm{~mm}$ mesh boxes $(181 \times 268 \times 31 \mathrm{~mm})$, thus an elementary layer for drying was formed, i.e. one layer per one part of the product. The prepared herbal raw material was dried in the oven Memmert UPF 700 at $39.9 \pm 0.26^{\circ} \mathrm{C}$ with the internal air circulation inside a chamber and outside air circulation between the chamber and environment. The intensity of outer air circulation was 18.1 volumes of the chamber per hour. Weight of dried samples and air parameters in the oven were recorded every 2-4 hours during drying.

Drying in a thick still layer. The prepared raw material of purple coneflower was dried by active ventilation; temperature of heated ambient air was 44.8 $\pm 1.5^{\circ} \mathrm{C}$ and relative humidity $-65.2 \pm 3.8 \%$. On the basis of recommendations (Raila et al., 2009; Čipliene et al., 2015), an average comparative ventilation intensity equal to $4100 \pm 550 \mathrm{~m}^{3}(\mathrm{t} \mathrm{h})^{-1}$ was maintained during the experiment. The drying experiment was conducted on a special test-bench with three drying containers, i.e. in ventilated cylinders $180 \mathrm{~mm}$ diameter and $1050 \mathrm{~mm}$ height (Fig. 1).

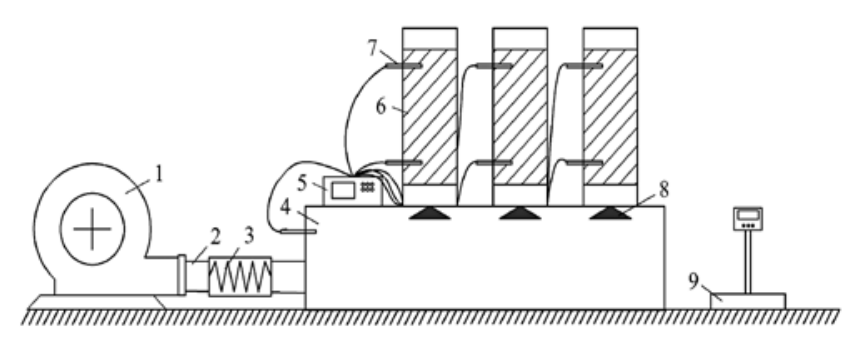

1 (fan 2) - flexible flange, 3 - electric heater EKA 125-0.9-1f, 4 - air distribution manifold, 5 - data logger, 6 - ventilated containers with herbal raw material, 7 - temperature and relative humidity sensors, 8 - valves, 9 - scales

Figure 1. The basic scheme of a test bench for material drying in a still thick layer 
For the drying conditions and drying process recording temperature and relative humidity sensors AHLBORN FH A646 (Ahlborn GmbH, Germany), accuracy of temperature measurement $\pm 0.1^{\circ} \mathrm{C}$, for humidity $\pm 2 \%$, were positioned in the air manifold and in ventilated containers: at the bottom of a container $(5-10 \mathrm{~cm}$ above the bottom of a herbal raw material layer) and at the top (5-10 $\mathrm{cm}$ below the top of the herbal raw material). The first ventilated container was filled with flowers of the purple coneflower, the second with chopped stems and the third with leaves. The drying containers were weighed periodically, every 6-8 hours, four times per day using scales VB 150K20 DLM (Kern \& Sohn GmbH, Germany). Weight variation of the medicinal plant raw material was monitored during the drying process.

Intensity of ventilation was controlled and velocity of air flow through the herbal raw material was measured with a thermo-anemometer Omegaflo HH-600, model $615 \mathrm{M}$ ("Omega", USA), accuracy $\pm 0.1 \mathrm{~m} \mathrm{~s}^{-1}$.

Biochemical analysis. The biochemical research for quality on dried medicinal plant raw material was carried out at Instrumental Analysis Laboratory, Vytautas Magnus University. Moisture content of all herbal raw material test samples was estimated according to a method, described in the European Pharmacopoeia (2014) (Ph. Eur. 2.2.32). The sample extracts were prepared from the test medicinal plant material, $0.5 \mathrm{~g}$ (accuracy $0.001 \mathrm{~g}$ ) of minced raw material were extracted in $20 \mathrm{ml}$ of $75 \%$ methanol solution with an orbital shaker for 24 hours, shaking intensity was 200 times per minute. The extracts derived were filtered with membranous filter, pore size $0.2 \mu \mathrm{m}$.

The total phenolic content was determined using a slightly modified Folin-Ciocalteu method (Singleton, Rossi, 1965). In $1052.4 \mathrm{ml}$ of bi-distilled water $35.08 \mathrm{~g}$ of dry sodium carbonate was dissolved. Standard solution of rutin $\left(0.01-1.00 \mathrm{mg} \mathrm{ml}^{-1}\right)$ was used $\left(R^{2}=0.982\right)$ for calibration of a diagram $100 \mu \mathrm{l}$ of sample extract was mixed with $3000 \mu \mathrm{l}$ of sodium carbonate solution (3.3\%). Samples were inverted two times and mixed with $100 \mu$ of Folin-Ciocalteu reagent $(2 \mathrm{~N})$; after 30 min of incubation at room temperature, absorbance was measured at $760 \mathrm{~nm}$ using a spectrophotometer Spectronic 1201 ("Milton Roy", USA). For the control sample 75\% methanol was mixed with sodium carbonate and Folin-Ciocalteu reagent solution instead of medical raw material extract. Analysis was conducted in the same conditions.

Total flavonoids content was evaluated according to a modified spectrophotometric assay using aluminium chloride method (Mabry et al., 2012). Stock reagent solution was prepared from $60 \mathrm{ml}$ of methanol (100\%), $3 \mathrm{ml}$ of acetic acid (33\%), $12 \mathrm{ml}$ of hexametylentetramine $(5 \%), 9 \mathrm{ml}$ of aluminium chloride $(10 \%)$ and $60 \mathrm{ml}$ of bi-distilled water before analysis. The calibration curve was prepared using standard solution $\left(0.01-1.00 \mathrm{mg} \mathrm{ml}^{-1}\right)$ of rutin $\left(R^{2}=0.999\right) .80 \mu \mathrm{l}$ of sample extract was added to $1920 \mu \mathrm{l}$ of stock solution $\left(+4^{\circ} \mathrm{C}\right)$ for the analysis. It was inverted two times and after $30 \mathrm{~min}$ of incubation in $+4^{\circ} \mathrm{C}$ temperature absorbance was measured at $407 \mathrm{~nm}$. The total flavonoids content (TFC) was expressed as mg rutin equivalent (RE) per $100 \mathrm{~g}$ of dry material (d.m.). For control sample $75 \%$ methanol was mixed with initial solution of reagent instead of medical raw material extract.

Radical scavenging activity was determined by using DPPH (2,2-diphenylpicrylhydrazyl) radical scavenger capacity method (Brand-Williams et al., 1995). The $100 \mathrm{mM}$ buffer solution ( $\mathrm{pH}$ 5.5) was prepared for analysis $-3.402 \mathrm{~g}$ sodium acetate was dissolved in 250 $\mathrm{ml}$ bi-distilled water. The acidity of solution was adjusted with $33 \%$ acetic acid. Initial DPPH solution was prepared after dissolving $10 \mathrm{mg}$ DPPH in acetonitrile and by adding $125 \mathrm{ml}$ methanol. This solution was mixed with $250 \mathrm{ml}$ of sodium acetate buffered solution and its absorbance was measured at $515 \mathrm{~nm}$. Absorbance was adjusted exactly to $0.500 \mathrm{AU}$ (absorption units) using buffered solution:acetonitrile:methanol $(2: 1: 1)$ and was kept in the dark. The calibration curve was prepared using standard solution of rutin $\left(0.05-0.25 \mathrm{mg} \mathrm{ml}^{-1}\right)$. Sample extract $(77 \mu \mathrm{L})$ or rutin solution was mixed with $3000 \mu \mathrm{L}$ of DPPH reagent solution and was inverted two times. After 15 min of incubation at room temperature in the dark, the absorbance was measured at $515 \mathrm{~nm}$. For control sample $75 \%$ methanol was mixed with initial solution instead of medical raw materials extract. Analysis was carried out in the same conditions.

Determination of chicoric acid. Additionally chicoric acid was determined in a thick still layer of dried raw materials. Reversed-phase high performance liquid chromatography (HPLC) system with reaction detector was used. Two chromatograms were recorded simultaneously. The upper chromatogram was obtained by registering UV absorbance at $254 \mathrm{~nm}$ of wave length prior to the reaction; a mirror chromatogram was recorded on visible light field at $517 \mathrm{~nm}$ after the reaction of effluent with DPPH solution in the reaction coil. Component $\mathrm{A}-0.05 \%$ trifluoroacetic acid was mixed with distilled water; component $\mathrm{B}-0.05 \%$ trifluoroacetic acid was prepared in methanol. Standard of chicoric acid was used, concentration: $0.1 \mathrm{mg} \mathrm{ml}^{-1} 75 \%$ in methanol. Extracts of samples were filtered through membranous $0.2 \mu \mathrm{m}$ filter. Components A and B were supplied using a pump Varian 9012 model ESC ("Varian", USA). Samples of $10 \mu \mathrm{l}$ were injected using Perkin Elmer Series 200 LC AutoSampler ("Norwalk", USA) auto injector. For analysis reversed-phase LiChroSpher RP-18e ("Merck", Germany), $5 \mu \mathrm{m} 12.5 \times 0.4 \mathrm{~cm}$ column and $0.5 \times 0.4 \mathrm{~cm}$ precolumn were used (Kaškonienė et al., 2011).

Statistical analysis. All results were based on three or more replicates. One-way analysis of variance ( $A N O V A$ ) was performed with $M S$ Excel to analyse the data. Significant difference $(p<0.05)$ between various preparation methods was determined with Fisher's LSD range test.

\section{Results and discussion}

In our previous research it was found, that weight of woody, rigid and branched in the upper third part stems accounted for $48.7 \pm 3.39 \%$ of the total weight of purple coneflower above-ground part, height of stems 
reached to $813 \pm 117 \mathrm{~mm}$, and the diameter of a stem in the thickest part was $6.95 \pm 1.1 \mathrm{~mm}$. Alternate-leaved, egg-lancet-shaped leaves are located on the stems; their length is $111 \pm 32 \mathrm{~mm}$ and width at leaf widest point $-56 \pm$ $10 \mathrm{~mm}$. The leaves accounted for $32.5 \pm 2.46 \%$ of weight of the yield. Weight of flowers formed the smallest aboveground part of plants $-18.82 \pm 3.23 \%$ (Zvicevičius et al., 2013). Flowers showed large dimensional scattering: the diameter and height of their receptacles varied from 14.2 to $36.0 \mathrm{~mm}$ and from 9.2 to $33.3 \mathrm{~mm}$, respectively.

Original moisture content of the individual morphological parts of purple coneflower was different. Moisture content of leaves was the highest $-79.25 \pm$ $2.09 \%$, moisture content of flowers was slightly lesser $78.39 \pm 1.72 \%$ and the lowest in stems $-68.18 \pm 1.7 \%$. In the course of drying of the separate morphological parts in elementary layer at $38.8 \pm 0.28^{\circ} \mathrm{C}$, drying of leaves was the fastest: up to $10 \%$ moisture content in 19.5 hours (Fig. 2). Whole stems and flowers had reached the same moisture content through 2.3 times longer period, approximately after 45-47 hours. Even though the diameter of flowers was higher than that of whole stems, flowers dried more intensively and evenly. The average drying rate of flowers was $1.74 \% \mathrm{~h}^{-1}$ and of the whole stems $-1.52 \% \mathrm{~h}^{-1}$.

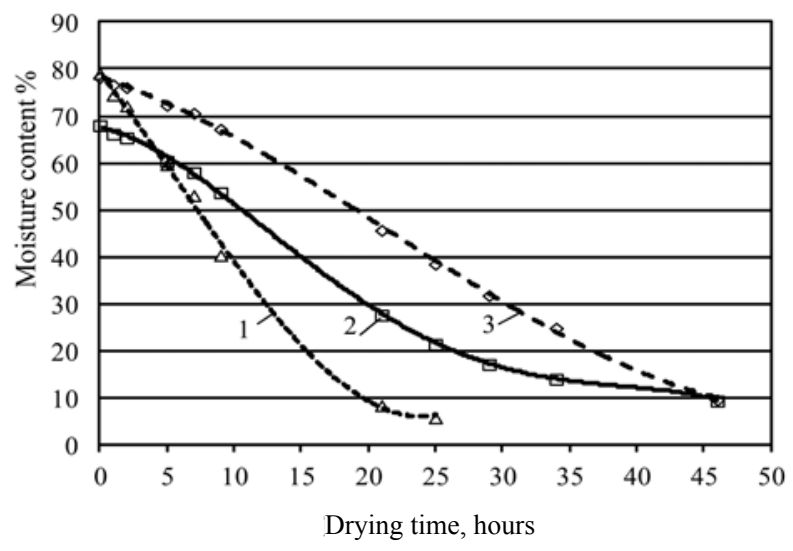

Figure 2. Variation of moisture content of different morphological parts of purple coneflower, in the course of drying in elementary layer: 1 - leaves, 2 - stems and 3 - flowers

Drying time of crushed and chopped stems and flowers was shorter (Fig. 3). The influence of mechanical impact was particularly evident in the stems' drying process; their drying time reduced by more than twice. Different methods of the purple coneflower preparation - crushing and chopping had no significant effect on the drying time, even though it had influence on colour of stems. The crushed stems lost their natural bright green colour and browned. Damages of plant cells created favourable conditions for the chlorophyll oxidation (Toivonen, Brummell, 2008). Changes in colour were not observed in mass of chopped stems. Flowers were only crushed for the experiment. Their drying time reduced as well, from 44.3 to 36.3 hours. The crushed flowers drying time became 8 times shorter. Although crushing had a huge impact on drying time of flowers, it was three times shorter compared with stems which had been processed mechanically. Hence mechanical processing had a smaller influence on the drying process of flowers compared with stems. The difference between reductions of drying time was more than 3 times lesser compared with drying time of crushed and uncrushed stems.

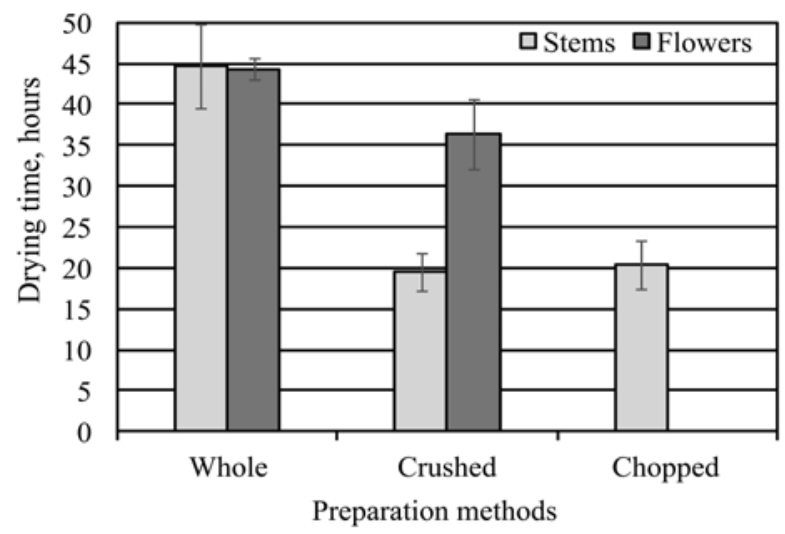

Figure 3. The influence of the preparation method of medicinal plant raw material on the drying time

In the course of drying of chopped purple coneflower stems, leaves and flowers in a thick still layer, at a temperature of drying agent $44.8 \pm 1.5^{\circ} \mathrm{C}$, relative humidity $65.2 \pm 3.8 \%$ and at average comparative ventilation intensity equal to $4100 \pm 550 \mathrm{~m}^{3}(\mathrm{t} \mathrm{h})^{-1}$, drying time of chopped stems was the shortest -29.5 hours (Fig. 4). Their moisture content decreased from $77.1 \pm 0.98 \%$ to $13.99 \%$. The purple coneflower leaves, characterised by the fastest change of moisture content in an elementary layer, dried the longest in a thick layer from $79.1 \pm 0.38 \%$ to $22.71 \pm 1.37 \%$ almost during four days. Similar flower and leaf drying time proportion was found by other authors, drying time of leaves was about $30 \%$ longer compared with drying time of flowers (Lin et al., 2011). However, ventilation which was used by the mentioned authors while drying stems in dryer was not very effective. According to their results, the longest drying time 41 hours was for $4 \mathrm{~cm}$ chaff of stems (Lin et al., 2011). While drying in an actively ventilated layer it only took 21 hours.

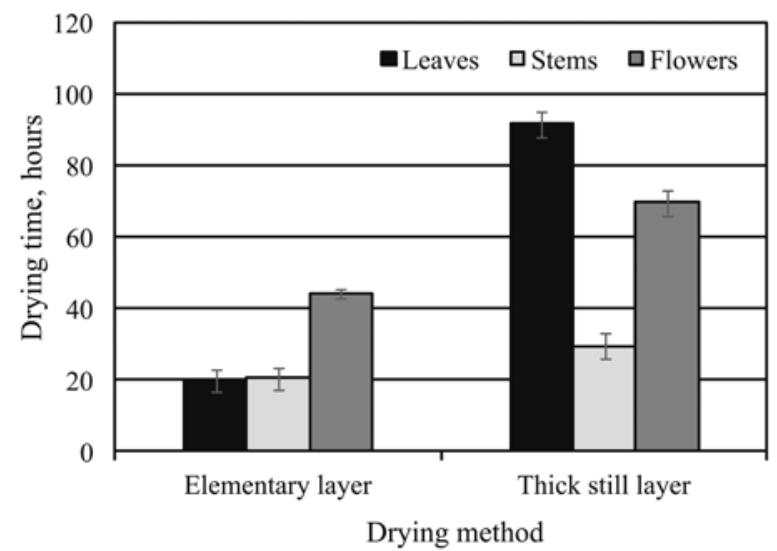

Figure 4. The influence of a drying method on drying time 
Leaves dried longer in a thick still layer because of the processes in a bulked layer: height and porosity of a heap decreased. Conditions of drying agents flow in a layer of herbal raw material and intensity of the moisture exchange processes changed because of changes in the mound. The minimum variation in the height of the bulked layer $(29.3 \%)$ was recorded in the layer of chopped stems (Fig. 5). The height of layers with leaves and flowers decreased by $56.97 \%$ and $54.58 \%$, respectively. Because of close to a ball and relatively firm shape of receptacles, the flowers had retained the porous bulked structure and more favourable conditions for distribution of drying agent; whilst flat shape of leaves resulted in squeeze of a layer, low porosity, poor aeration conditions in the layer and in long drying time.

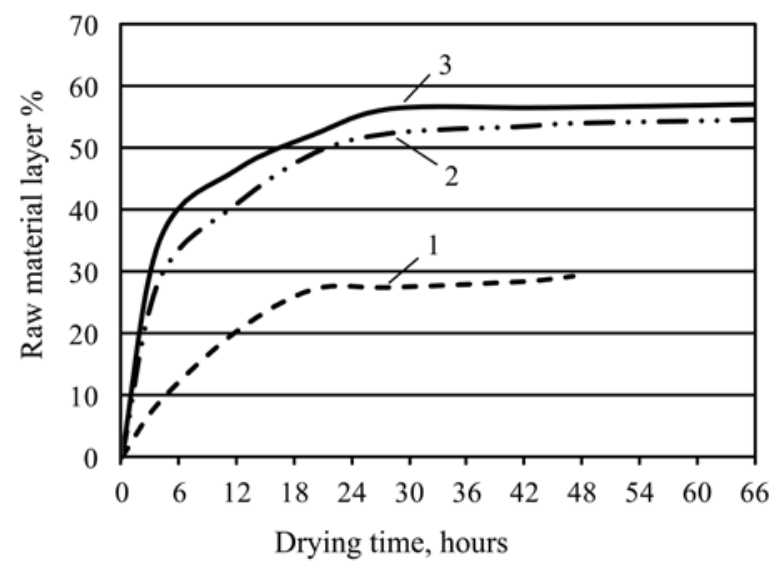

Figure 5. Decrease of a raw material layer during the process of drying in a thick layer
Evaluation of the quality of dried purple coneflower plant raw material showed that the highest phenolic compounds content was in the flowers, dried in an elementary as well as in a still thick layer (Table). The lowest content of phenolic was found in stems. Likewise, a similar trend was determined by other scientists, involved in purple coneflower studies; the content of phenolic for leaves increased compared with stems but decreased compared with blossoms (Lin et al., 2011). The study results showed that drying in an elementary layer was more favourable for the preservation of phenolic. Their content in flowers and leaves was higher in comparison with the samples dried in a thick still layer. This was the result of different drying time: by drying up flowers and leaves in an elementary layer, their drying time was by 1.57 (25.17 hours) and 4.65 (71.83 hours) times shorter, respectively than by drying in a thick still layer.

Phenolic compounds, found in the above-ground parts of purple coneflower, are assigned to two large groups: flavonoids and phenolic acids. Phenolic acids made up the biggest part of phenolic found in the test samples. In herbal raw material dried in an elementary layer, the acids amounted to $90 \%$ of the total content of phenolic compounds, whilst in a thick still layer - more than $71 \%$. This was confirmed by the results obtained by Wojdyło et al. (2007). They stated that phenolic acids formed the main part of phenolic compounds in purple coneflower. The most important compound in this group is chicoric acid (Lin et al., 2011). Its amount in flowers, leaves and stems, dried in a thick still layer was $24.08 \pm$ $0.6,11.14 \pm 0.36$ and $8.48 \pm 0.04 \mathrm{mg} \mathrm{g}^{-1}$, respectively.

Table. The quantity of biologically active substances

\begin{tabular}{|c|c|c|c|c|c|c|c|c|}
\hline & \multicolumn{4}{|c|}{ Drying in an elementary layer } & \multicolumn{4}{|c|}{ Drying in a thick still layer } \\
\hline & TPAC & TFC & $\mathrm{TPC}$ & RSA & TPAC & TFC & $\mathrm{TPC}$ & RSA \\
\hline & $\mathrm{g}_{\text {d.m. }}{ }^{-1} \mathrm{RE}$ & $\underset{\mathrm{g}_{\mathrm{d} . \mathrm{m} .}{ }^{-1} \mathrm{RE}}{\mathrm{mg}}$ & $\underset{\mathrm{g}_{\text {d.m. }}{ }^{-1} \mathrm{RE}}{\mathrm{mg}}$ & $\underset{\mathrm{g}_{\mathrm{d} . \mathrm{m} .}{ }^{-1} \mathrm{RE}}{\mathrm{mg}}$ & $\mathrm{g}_{\text {d.m. }}{ }^{-1} \mathrm{RE}$ & $\underset{\mathrm{g}_{\text {d.m. }}{ }^{-1} \mathrm{mE}}{\mathrm{mg}}$ & $\mathrm{g}_{\text {d.m. }}{ }^{-1} \mathrm{RE}$ & $\underset{\mathrm{g}_{\text {d.m. }}{ }^{-1} \mathrm{RE}}{\mathrm{mg}}$ \\
\hline Flowers & $92.08 \pm 4.60$ & $8.15 \pm 0.41$ & $100.23 \pm 5.01$ & $24.79 \pm 1.24$ & $64.66 \pm 3.23$ & $26.02 \pm 1.30$ & $90.68 \pm 4.53$ & $45.24 \pm 2.26$ \\
\hline Leaves & $76.9 \pm 3.85$ & $8.12 \pm 0.41$ & $85.02 \pm 4.25$ & $36.92 \pm 1.85$ & $47.46 \pm 2.37$ & $14.86 \pm 0.73$ & $62.05 \pm 3.10$ & $29.34 \pm 1.47$ \\
\hline Stems & $20.96 \pm 1.05$ & $0.03 \pm 0.002$ & $20.99 \pm 1.05$ & $8.09 \pm 0.41$ & $23.00 \pm 1.15$ & $8.97 \pm 0.45$ & $31.97 \pm 1.60$ & $13.45 \pm 0.67$ \\
\hline
\end{tabular}

TPAC - total phenolic acids content, TFC - total flavonoids content, TPC - total phenolic content, RSA - radical scavenging activity, determined by DPPH method; d.m. - dry material, RE - rutin equivalent

Although the concentration of flavonoids in purple coneflower is not high, smaller quantities of flavonoids were found in medicinal plant raw material after process of drying in an elementary layer. Overdrying of the purple coneflower morphological parts could have an influence on that. Moisture content of the purple coneflower dried in an elementary layer was $4-6 \%$ lesser compared with that of the purple coneflower dried in a thick still layer. Moisture content of flowers, leaves and chopped stems in an elementary layer was $5.22 \pm 1.84$, $3.74 \pm 1.03$ and $4.54 \pm 0.46 \%$, respectively. In addition, in the course of drying in an elementary layer, contacts between the surface of herbal raw material and air flow were more intensive than by drying it in a thick still layer.
It is suggested in literary sources that flavonoids are relatively resistant to heat; however, they are sensitive to the oxidation effects (Barrett et al., 2010), and therefore the excessive ventilation is destructive to the flavonoids.

It was determined by spectral-photometric research that different preparation for drying of the purple coneflower flowers had no significant effect on flavonoids content (Fig. 6). The quantity of phenolic content and phenolic acids in crushed flowers was 0.2 times lower compared with healthy flowers. Total content of phenolic and phenolic acids in crushed flowers was $83.3 \pm 4.2$ and $74.7 \pm 3.7 \mathrm{mg} \mathrm{g}_{\mathrm{d} . \mathrm{m} .}{ }^{-1} \mathrm{RE}$, respectively. Higher radical scavenging activity was determined in crushed flowers $\left(47.78 \pm 2.39 \mathrm{mg} \mathrm{g}_{\text {d.m. }}{ }^{-1} \mathrm{RE}\right)$ than in 
whole flowers $\left(36.92 \pm 1.85 \mathrm{mg} \mathrm{g}_{\text {d.m. }}{ }^{-1} \mathrm{RE}\right)$. This could be the result of losses of the biologically active substances with different antioxidant activities that occurred during drying. Each of the biologically active substances has different antioxidant activity (Javanmardi et al., 2003; Hossain et al., 2010). More extensive research should be conducted in order to evaluate the influence of drying conditions on antioxidant activity of the medicinal plant raw material.

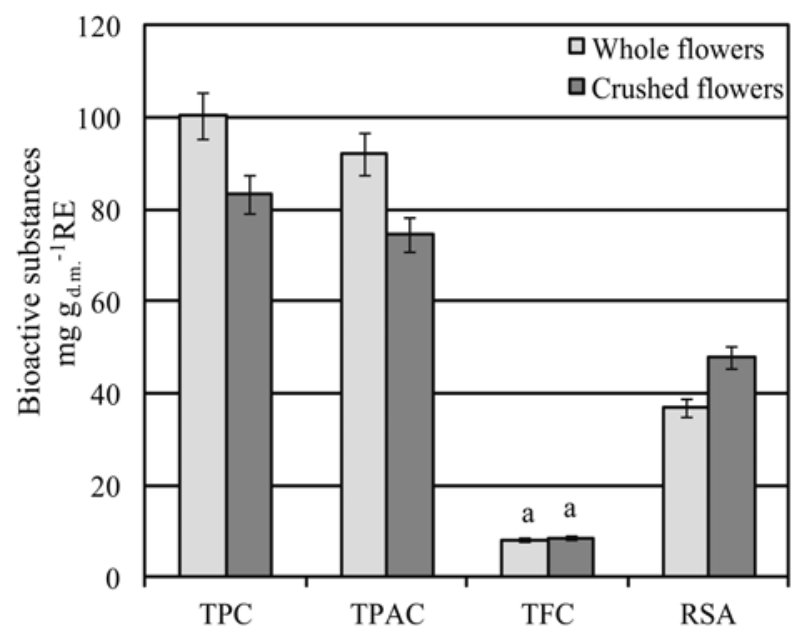

Note. Explanations of abbreviations under Table; columns marked with same letter are not significantly different at $P \leq 0.05$.

Figure 6. The influence of preparation of the purple coneflower flowers on the quantity of biologically active substances in dried samples

The same flavonoid content $(0.03 \pm 0.0015 \mathrm{mg}$ $\mathrm{g}_{\mathrm{d} . \mathrm{m} .}{ }^{-1} \mathrm{RE}$ ) was determined in stem samples dried in an elementary layer regardless of the preparation method. However, the mechanical preparation for drying had a direct influence on contents of phenolic and phenolic acids in the purple coneflower raw material (Fig. 7).

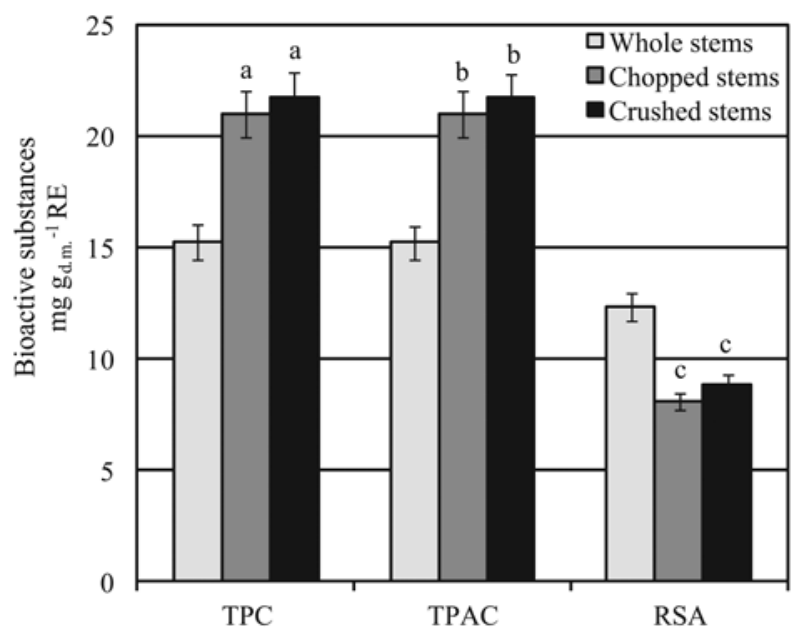

Note. Explanations of abbreviations under Table; columns marked with same letter are not significantly different at $P \leq$ 0.05 .

Figure 7. The influence of raw material preparation on the quantity of biologically active substances
As was mentioned above, duration of drying of crushed and chopped stems decreased by more than twice. This resulted in approx. 30\% higher total phenolic and phenolic acids contents in raw material: their maximum content was found in crushed stems -21.75 \pm 1.09 and $21.72 \pm 1.09 \mathrm{mg} \mathrm{g}_{\text {d.m. }}{ }^{-1} \mathrm{RE}$, respectively. The contents of phenolic and phenolic acids in chopped stems were found to be: $20.99 \pm 1.05$ and $20.96 \pm 1.05 \mathrm{mg}$ $\mathrm{g}_{\mathrm{d} . \mathrm{m} .}{ }^{-1} \mathrm{RE}$, respectively. Mechanical processing of the morphological parts of purple coneflower accelerates drying and improves the quality of the raw material.

\section{Conclusions}

1. Stems and flowers, which are rigid morphological parts, of a harvested purple coneflower plant form a porous bulk layer with a stable structure that leads to more favourable drying conditions of raw material in a still thick layer and to more intensive drying.

2. Crushing of the purple coneflower flowers reduced the drying time by 8 hours - from 44.3 to 36.3 hours and the quantity of phenolic compound and phenolic acid in crushed flowers was 0.2 times lower than in healthy flowers.

3. In the course of drying of crushed and chopped purple coneflower stems in an elementary layer at $39.9 \pm$ $0.26^{\circ} \mathrm{C}$, as compared with the whole stems, their drying time reduced from 43 to 19.5 hours, whilst phenolic content and phenolic acids content remained by $30 \%$ higher on average. The phenolic content in the whole, chopped and crushed stems was $15.23 \pm 1.05,20.99 \pm$ 1.05 and $21.75 \pm 1.09 \mathrm{mg} \mathrm{g}_{\text {d.m. }}{ }^{-1} \mathrm{RE}$, respectively.

4. Phenolic acids constituted the biggest part of phenolic compounds found in flowers, leaves and stems of purple coneflower. The distribution of phenolic acids in different above-ground parts of a plant was as follows: $64.66 \pm 3.23$ to $92.08 \pm 4.60 \mathrm{mg} \mathrm{g}_{\text {d.m. }}{ }^{-1} \mathrm{RE}$ in flowers, $47.46 \pm 2.37$ to $76.9 \pm 3.85 \mathrm{mg} \mathrm{g}_{\text {d.m. }}{ }^{-1}$. $R E$ in leaves and $15.2 \pm 1.05$ to $22.99 \pm 1.15 \mathrm{mg} \mathrm{g}_{\mathrm{d} . \mathrm{m} .}{ }^{-1} \mathrm{RE}$ in stems.

5. When drying individual morphological parts of purple coneflower at a temperature of the drying agent of $38-44^{\circ} \mathrm{C}$ in elementary layer, drying time varied from 19.7 to 91.5 hours, and in thick still layer whose height was $73 \pm 8.2 \mathrm{~cm}$ varied from 29.5 to 91.5 hours. Drying duration of stems, flowers and leaves increased 1.45, 1.57 and 4.65 times. Drying duration lengthened by 9.2, 25.17 and 71.83 hours, respectively.

6. Mechanical processing (crushing or grinding) can be used for plant stems to increase the drying intensity and shorten the drying time as well as to preserve a greater amount of biologically active materials.

Received 09042015 Accepted 15062015 


\section{References}

Abbasi B. H., Saxena P. K., Murch S. J., Liu C.-Z. 2007. Echinacea biotechnology: challenges and opportunities. In vitro cellular and developmental biology - Plant, 43 (6): 481-492

http://dx.doi.org/10.1007/s11627-007-9057-2

Arabhosseini A., Huisman W., Boxtel A., Müller J. 2007. Longterm effects of drying conditions on the essential oil and color of tarragon leaves during storage. Journal of Food Engineering. 79 (2): 561-566 http://dx.doi.org/10.1016/j.jfoodeng.2006.02.014

Argyropoulos D., Müller J. 2014. Changes of essential oil content and composition during convective drying of lemon balm (Melissa officinalis L.). Industrial Crops and Products, 52: 118-124 http://dx.doi.org/10.1016/j.indcrop.2013.10.020

Barrett D. M., Beaulieu J. C., Shewfelt R. 2010. Color, flavor, texture, and nutritional quality of fresh-cut fruits and vegetables: desirable levels, instrumental and sensory measurement, and the effects of processing. Critical Reviews in Food Science and Nutrition, 50 (5): 369-389 http://dx.doi.org/10.1080/10408391003626322

Brand-Williams W., Cuvelier M. E., Berset C. 1995. Use of a free radical method to evaluate antioxidant activity. LWTFood Science and Technology, 28 (1): 25-30 http://dx.doi.org/10.1016/S0023-6438(95)80008-5

Čiplienė A., Novošinskas H., Raila A., Zvicevičius E. 2015. Usage of hybrid solar collector system in drying technologies of medical plants. Energy Conversion and Management, 93: 399-405

http://dx.doi.org/10.1016/j.enconman.2015.01.051

European Pharmacopoeia ( $8^{\text {th }}$ ed. $), 2014$

Dambrauskienė E. 2006. Productivity of eastern purple coneflower (Echinacea purpurea L. Moench) applying intensive growing technologies. Sodininkyste ir daržininkystè, 25 (4): 316-321 (in Lithuanian)

Diatta J., Grzebisz W., Frąckowiak-Pawlak K.,Andrzejewska A., Brzykcy M. 2014. Site-specific evaluation of Cu, Zn, Fe and $\mathrm{Mn}$ availability in arable soils. Zemdirbyste-Agriculture, 101 (3): $235-242$ http://dx.doi.org/10.13080/z-a.2014.101.030

Hossain M. B., Barry-Ryan C., Martin-Diana A. B., Brunton N. P. 2010. Effect of drying method on the antioxidant capacity of six Lamiaceae herbs. Food Chemistry, 123 (1): 85-91 http://dx.doi.org/10.1016/j.foodchem.2010.04.003

Javanmardi J., Stushnoff C., Locke E., Vivanco J. M. 2003. Antioxidant activity and total phenolic content of Iranian Ocimum accessions. Food Chemistry, 83 (4): 547-550 http://dx.doi.org/10.1016/S0308-8146(03)00151-1

Kaškonienè V., Bimbiraitè-Survilienè K., Ratautaitė V., Stankevičius M., Kornyšova O., Ragažinskienė O., Proscevičius J., Maruška A. 2011. Investigation of phytochemical composition of biotechnologically modified medicinal plants. Sodininkystè ir daržininkystè, 30 (1): 23-33

Kim H. O., Durance T. D., Scaman Ch. H., Kitts D. D. 2000. Retention of caffeic acid derivatives in dried Echinacea purpurea. Journal of Agricultural and Food Chemistry, 48 (9): 4182-4186 http://dx.doi.org/10.1021/jf000245v

Lin S. D., Sung J. M., Chen Ch. L. 2011. Effect of drying and storage conditions on caffeic acid derivatives and total phenolics of Echinacea purpurea grown in Taiwan. Food Chemistry, 125 (1): 226-231 http://dx.doi.org/10.1016/j.foodchem.2010.09.006

Lugauskas A., Paškevičius A., Repečkienė J. 2002. Pathogenic and toxic microorganisms in human environment, $434 \mathrm{p}$. (in Lithuanian)

Mabry T. J., Markham K. R., Thomas M. B. 2012. The systematic identification of flavonoids. Berlin, Heidelberg, $354 \mathrm{p}$.
Mačkinaite R. 2011. Internal mycobiota of wild and cultivated common caraway (Carum carvi L.) seeds. ZemdirbysteAgriculture, 98 (2): 184-194

Mistríková I., Vaverková Š. 2007. Morphology and anatomy of Echinacea purpurea, E. angustifolia, E. pallida and Parthenium integrifolium. Biologia, 62 (1): 2-5 http://dx.doi.org/10.2478/s11756-007-0006-7

Müller J., Heindl A. 2006. Drying of medicinal plants. Bogers R. J. et al. (eds.). Medicinal and aromatic plants, p. $237-252$ http://dx.doi.org/10.1007/1-4020-5449-1_17

Murch S. J., Peiris S. E., Shi W. L., Zobayed S. M. A., Saxena P. K. 2006. Genetic diversity in seed populations of Echinacea purpurea controls the capacity for regeneration, route of morphogenesis and phytochemical composition. Plant Cell Reports, 25 (6): 522-532 http://dx.doi.org/10.1007/s00299-006-0118-5

Prickett A. J., Macdonald S., Wildey K. B. 2000. Home-grown cereals authority. Survey of mycotoxins in stored grain from the 1999 harvest in the U.K

Ragažinskienè O., Rimkienè S. 2003. Medicinal and aromatic plants genetic resources and cultivation in Lithuania. Journal of Medicinal and Spice Plants, 8 (4): 189-191

Raila A., Lugauskas A., Kemzuraite A., Zvicevicius E., Ragazinskiene O., Railiene M. 2009. Different drying technologies and alternation of mycobiots in the raw material of Hyssopus officinalis L. Annals of Agricultural and Environmental Medicine, 16 (1): 93-101

Raila A., Ragažinskienė O., Novošinskas H., Zvicevičius E., Čiplienè A., Volkavičiūtė Ž., Kemzūraitė A. 2014. Vaistinès augalinès žaliavos auginimo ir džiovinimo technologijos: rekomendacijos vaistinių ir prieskoninių augalu augintojams ir perdirbejams. Aleksandras Stulginskis University, Vytautas Magnus University, 63 p. (in Lithuanian)

Sárosi Sz., Sipos L., Kókai Z., Pluhár Zs., Szilvássy B., Novák I. 2013. Effect of different drying techniques on the aroma profile of Thymus vulgaris analyzed by GC-MS and sensory profile methods. Industrial Crops and Products, 46: $210-216$ http://dx.doi.org/10.1016/j.indcrop.2013.01.028

Singleton V. L., Rossi J. A. 1965. Colorimetry of total phenolics with phosphomolybdic-phosphotungstic acid reagents. American Journal of Enology and Viticulture, 16 (3): $144-158$

Stuart D. L., Wills R. B. H. 2003. Effect of drying temperature on alkylamide and cichoric acid concentrations of Echinacea purpurea. Journal of Agricultural and Food Chemistry, 51 (6): 1608-1610 http://dx.doi.org/10.1021/jf026213k

Toivonen P. M. A., Brummell D. A. 2008. Biochemical bases of appearance and texture changes in fresh-cut fruit and vegetables. Postharvest Biology and Technology, 48 (1): $1-14$ http://dx.doi.org/10.1016/j.postharvbio.2007.09.004

Tsai Y. L., Chiou Sh. Y., Chan K. Ch., Sung J. M., Lin Sh. D. 2012. Caffeic acid derivatives, total phenols, antioxidant and antimutagenic activities of Echinacea purpurea flower extracts. LWT-Food Science and Technology, 46 (1): $169-176$ http://dx.doi.org/10.1016/j.lwt.2011.09.026

Wojdyło A., Oszmiański J., Czemerys R. 2007. Antioxidant activity and phenolic compounds in 32 selected herbs. Food Chemistry, 105 (3): 940-949 http://dx.doi.org/10.1016/j.foodchem.2007.04.038

Zvicevičius E., Novošinskas H., Ciplienė A., Ragažinskienė O., Bartusevičius V. 2013. Differences in drying processes of morphological parts of purple coneflower (Echinacea purpurea L. Moench). $12^{\text {th }}$ international scientific conference Engineering for Rural Development. Jelgava, Latvija, p. 142-146 
ISSN 1392-3196 / e-ISSN 2335-8947

Zemdirbyste-Agriculture, vol. 102, No. 3 (2015), p. 297-304

DOI $10.13080 /$ z-a.2015.102.038

\title{
Rausvažiedžių ežiuolių paruošimo būdų ir džiovinimo technologijų įtaka biologiškai veiklių medžiagų kiekiui
}

\author{
A. Čiplienè ${ }^{1}$, A. Maruška ${ }^{2}$, A. Raila ${ }^{1}$, E. Zvicevičius ${ }^{1}$, O. Ragažinskienė ${ }^{3}$, M. Stankevičius ${ }^{2}$ \\ ${ }^{1}$ Aleksandro Stulginskio universitetas \\ ${ }^{2}$ Vytauto Didžiojo universitetas \\ ${ }^{3}$ Vytauto Didžiojo universiteto Kauno botanikos sodas
}

\section{Santrauka}

Lietuvoje vienas perspektyviausių vaistinių augalų yra rausvažiedė ežiuolè (Echinaceae purpureae (L.) Moench). Jos vaistinėje augalinėje žaliavoje sukaupiama daugiau nei 200 biologiškai aktyvių medžiagų komponentų; vieni svarbiausių - fenolinès rūgštys, tarp jų ir cikorinè rūgštis. Ką tik nuimtos rausvažiedès ežiuolès žaliavos drègnis gali būti iki 80 \%. Jam sumažinti dažniausiai taikomos ịvairios džiovinimo technologijos, kurių metu patiriami biologiškai veiklių medžiagų nuostoliai. Siekiant nustatyti rausvažiedžių ežiuolių paruošimo būdų bei džiovinimo technologijų įtaką džiūvimo procesui ir vaistinès augalinès žaliavos kokybei, buvo atlikti eksperimentiniai palyginamieji tyrimai. Nustatyta, kad rausvažiedžių ežiuolių stiebai sudaro 48,7 \% augalo masès ir yra didžiausia jų antžeminè dalis, atitinkamai 1,5 ir 2,6 karto viršijanti lapų bei žiedų masę. Rausvažiedžių ežiuolių žieduose, lapuose ir stiebuose didžiausią dalị fenolinių junginių sudarė fenolinės rūgštys. Tyrimų metu buvo nustatytas jų pasiskirstymas ịvairiose augalo antžeminèse dalyse: žieduose - nuo 64,66 $\pm 3,23$ iki 92,08 $\pm 4,60 \mathrm{mg} \mathrm{g}_{\mathrm{s}, \mathrm{m} .}{ }^{-1} \mathrm{RE}$

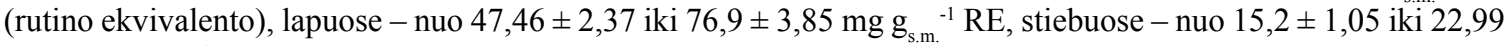
$\pm 1,15 \mathrm{mg} \mathrm{g}_{\mathrm{s} . \mathrm{m} .}{ }^{-1} \mathrm{RE}$.

Reikšminiai žodžiai: biologiškai veiklios medžiagos, džiovinimo technologijos, vaistiniai augalai. 